revives of the times when we occupied the same seat, or rather seats side by side in the House of Rep's. and later on our service in the Senate. Of course we did not think alike and act together upon all questions, but it is surely a pleasure to us both to know that there never was any disagreement to disturb the friendly relations which have always existed.

I thank you for your kind and friendly suggestions, made from your official experience here and your knowledge of the Spanish people. I can understand their force and correctness. Indeed I have marked out for myself as nearly as possible the course you suggest.

I have been aware that there is much of historic interest in Spain to be seen. The localities you name, as well as others, I intend to visit while I remain in this Legation. Indeed that was the great inducement for me to go abroad. $* * *$ The business of this Legation has largely increased since you were at its head; so while I may not have quite as much leisure as you found, yet I will have enough to see all that is of decided interest in Spain and $\mathrm{I}$ mean to do so.

I will endeavor to find a copy of paper containing what I said to the King and his reply. His reception was very cordial, and I was very favorably impressed with the appearance of both the King and Queen. ***

Will also from time to time endeavor to send you a paper as you request. In haste but with pleasant memories of "auld lang syne," I am,

Very truly yours,

H. HAMLIN,

\title{
DIARY KEPT BY WILLIAM EDMUNDSON, OF OSKA- LOOSA, WHILE CROSSING THE WESTERN PLAINS IN 1850.
}

Left Oskaloosa, Iowa, in the Stage on Monday morning, May 20 th, 1850, and arrived on the evening of the same day at Fort Des Moines and found my company 9 in number encamped on Raccoon River about a mile from the Town. River.

May 21st-Traveled about 22 miles and camped on the North

May 22nd-Traveled 23 miles and encamped on the Middle River North Side. This day it commenced raining Slowly about 12 Oclock and continued till near Sundown.

May 23rd-This morning it commenced raining before day and continued till about 10 Oclock when we Started and Traveled 15 


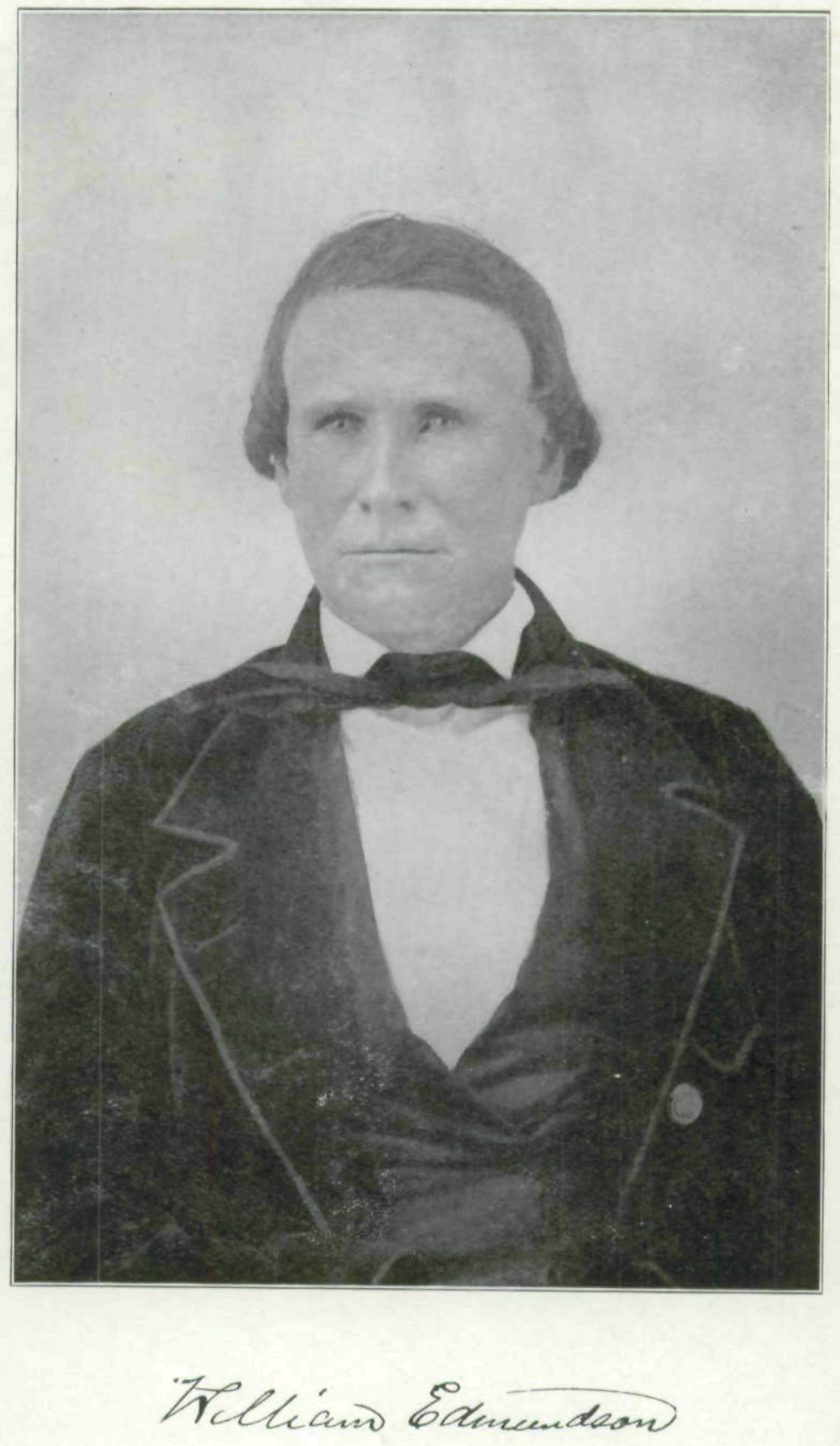


miles where we crossed Middle River and went 5 miles further and camped in the prairie hauling wood from the last Timber. This day was cloudy with occasional Showers.

May 24th-Traveled 12 miles and crossed The East branch of the Nodaway about noon went 12 miles further and camped on the West branch of the Nodaway. Saw but little Timber to day and that at a great distance except where we camped at night There being a Small grove on the Creek.

May 25th-Traveled 15 miles and came to the East branch of the Nishnabotany crossed Over and went down the creek about a mile to Indian Town a Mormon Settlement of 7 families being on the Site of an Old Potawatamie village We then went 7 miles further and camped in the Prairie hauling wood from Indian Town.

May 26th-Went 8 miles and came to a beautiful grove where there is a Mormon Settlement. Then 5 miles to The west fork of the Nishnabotany. Then 10 miles to Silver Creek where There is a Mormon village or Settlement.

May $27 t h$-This morning it commenced raining before day and rained very hard accompanied by Thunder and Lightning but cleared off about 6 Oclock. We Started about 9 Oclock and Traveled 8 miles to Keg Creek. Then 10 miles to Kanesville. The head quarters of the Mormans in Iowa and Situated about 4 miles from the Missouri River near the lower end of the Council Bluffs at a place formerly Called Indian Hollow. A. W. Hildreth from Highland County, Ohio, Settled here in 1839 and built a Saw mill within the present limits of the Town. The Potawatomie mills on Musketoe Creek are in 2 miles of this place. They were built for The Indians Some years ago by the U. S. Government. Kanesville contains 5 or 6 hundred inhabitants. They do a flourishing business in The mercantile line Owing Chiefly to the California emigration. The Frontier Guardian a weekly Newspaper is published here Elder Orson Hyde Editor. (We camped 2 miles below the Town.)

May 28th-This day we went to Kanesville and Bought provisions and Some other articles for our journey and in the afternoon moved about 6 miles down the river and camped on Musketoe Creek back of St. Francis (Trader's point) about one mile from the Town. (The 6 miles to day not included in an estimate of distances.)

May $29 t h$-Remained at our encampment. Some of the company went To Kanesville.

May 30 th-A sufficient number of Teams having arrived during the day we joined them and organized into a company amounting in all to 50 men and 2 women. 
May 31st-Crossed the river at St. Francis, or Traders Point, landing at Bellvue where The Agency for the Pawnees, Ottoes \& Omahas is located; An Indian School under the direction of the Presbyterian church is established about a mile from the agency under the Superintendence of the Rev. Wm. McKinney; here the traveler may be said to commence his journey across the Plains; The School or Mission being the last Settlement till we reach Fort Laramie a distance of 522 miles.

June 1st-Some of the wagons being out of order, it became necessary to stay till the afternoon in order to have them repaired upon which 26 of our company left us and went ahead. After getting the wagons ready we Started about one O'clock P. M. and went 5 miles and Camped on Spring Creek.

June 2nd-Started early, went 4 miles and crossed a Creek called the Pipeo. Then 8 miles to the little Pipeo where there is a small Grove and a good Spring. Then 8 miles to the Ferry on the Elkhorn which is here about 150 yards wide one and a half miles from its mouth here there is some Timber and the Country at this point seems susceptable of Settlement. After crossing we camped about 200 yards from the Elkhorn. Soon after stoping 300 Pawnees came up going toward the Missouri river, and camped between us and the Ferry.

June $3 r d$-Soon after Starting we got stalled in a marsh which detained us for some time, after going 9 miles we came to Platte river which is here about one-third of mile wide, in appearance it resembles the Missouri, being muddy and rapid with a continued succession of Boils and Eddies, though the water is said to be very shallow. After stoping a short time to Graze and Water the Horses we went about 9 miles further, 2 miles beyond the confluence of Winter quarters and Agency Roads, and camped at a grove of Timber on the Platte river; Having procured a Mormon Guide Book at Kanesville in which places and distances are laid down with great accuracy, we are enabled to know the exact distance Traveled in a day or from one point to another. This day we Traveled 18 miles. A few Indians Camped with us having followed us all the afternoon for the purpose of Beging. About Sundown a heavy rain commenced falling accompanied by Thunder \& Lightning which continued till about 10 O'clock when the rain ceased, but the night continued to be very dark and cloudy, there being no moonlight.

June 4 th-Went 13 miles and stoped for noon opposite an Island in Platte river. This Island looks at a distance like a grave in the Prairie. Went 11 miles further and camped on Shell Creek. This night the rain commenced about dark and continued till near 
day. Soon after stoping we were visited by 12 Pawnee wariors; they said they were a part of a company of 60 who were encamped a short distance from us across the creek. We gave them some Small presents in the way of Provisions, upon which they left us. They were probably a war party out against the Sioux.

June 5th-Early this morning we ran our wagons across Shell Creek by hand on a Temporary Bridge made of Brush the waters being high on account of the late rains; Started about 9 Oclock; This day it commenced raining soon after we started and continued till about 2 Oclock P. M. Soon after which we came to the river again and camped. The river here is near a mile wide. This day we Traveled only 12 miles. The roads being very bad in consequence of the rains.

June 6 th-Started at 8 O'clock and went 11 miles to the Ferry on the Loup Fork. The Ferrymen were gone and the Boat sunk. we attempted to raise it but found it so much damaged as to be unfit for use. we then took the road up the Loup Fork to the Ford which is 48 miles from the Ferry, went 9 miles and camped at Looking glass creek near a small Lake; Traveled 20 miles to day.

June $7 t h$-Started late this morning having to repair a bridge before crossing the creek. Traveled 9 miles to Beaver River a stream about 10 yards wide and very deep. We had to unload our wagons and carry the contents across on a Temporary Bridge formed of a $\log$ and some Brush we then drew the empty wagons across by Ropes and swam the Horses and Oxen we finished crossing about 3 Oclock went $61 / 2$ miles further and camped on Plumb creek near the site of Old Pawnee Missionary Station and 2 miles from the ruins of the Grand Pawnee village. The Mission was removed I believe in consequence of the Pawnees being driven from that part of the Country and the village above mentioned being burned by the Sioux in 1846. Traveled $15 \frac{1}{2}$ miles to day.

June $8 t h$-Started early and after Traveling 2 miles came to the ruins of the principal vilage of the Grand Pawnees and Tappas (the one refered to in the notes of yesterday) it is enclosed by a wall built of Sod in the manner of an ordinary Sod fence the wall is about 6 feet high and is still entire. it contains an Area of about 30 or 40 acres; from appearances the village Seems to have had a large Population; after leaving the old vilage we Traveled 4 miles to Cedar Creek a stream 8 rods wide the water being deep we proped our wagon beds up on Block so as to raise them a foot higher and then forded the stream without damage, in the afternoon a storm coming on we stoped early and camped at the foot of a Bluff, here there is the remains of Some old embankments 
but for what purpose they were thrown up is uncertain; Some of our men having been out hunting during the day saw several Buffalo but could not get near them, Traveled 17 miles to day.

June 9 th-Went 6 miles to the Loup Fork which we forded by laying poles across the tops of our wagon Beds and piling the loads on the top then taking the wagons across by hand the river is here about 300 yards wide about three feet deep very rapid and full of quick sand. We commenced at 11 Oclock A. M. and finished crossing about sundown camping on the western bank of the river, here we overtook the company who had left us on the Missouri river, they had crossed the day before and had stoped to rest, Traveled 6 miles to day.

June 10th-Started rather late the road for, the first 7 miles being over a high ridge very sandy and broken with numerous ponds and Basins, the next 18 miles the country is flat and rather marshy, we camped on Prairie Creek having again overtaken the company who left us at the Missouri river, they had started before us in the morning; We Traveled 25 miles to day.

June 11th-Started early the Country very level and tolerably dry. Traveled 11 miles and come to Wood river, unloaded the -wagons and carried the loads over on the horses then brought the wagons over empty. Went 7 Miles further and camped in the Prairie about one mile from the Platte river. 18 miles to day.

June 12th-Cool and cloudy this morning. The country level and dry. Traveled 7 miles and came to Platte River. This day we passed through several Towns of Prairie-Dogs. They bear some resemblance to the Gopher are of a yellowish grey color and are about the size of a small Rabbit. They live on the Prairie grass, The soda or alkali so much dreaded on the plains begins to make its appearance to day lying in a thin crust in the Buffalo beats where the sun has dried up the water. Traveled 25 miles to day and camped near Platte river.

June $13 t h$-Started at 7 Oclock Keeping up the Valey of Platte River, passed through a great many Dog-Towns to day some of them deserted most probably on account of the inhabitants having consumed all the grass in their vicinity which compelled them to seek a new location. Saw a good many dead Buffalo to day which had been killed by emigrants ahead of us. Saw a train across the river to day, Traveled 25 miles and camped near the river. (Plumb Creek.)

June 14th-Traveled only 15 miles to day still following up the Platte river, at noon we saw where a coal-Pitt had been burned, this is about 240 miles from the nearest settlement. the train across the river is still in sight. (5 miles east of Willow Island.) 
June 15th-Saw some Buffalo to day but at a considerable distance, at noon we came to Ptah Lake or Bayou where we saw Edward Haggard's grave who died on his way to California, he is buried on the Bank of the Ptah Lake about half way from the Council Bluffs to Fort Laramie. According to the inscription on the head-board he died on the 7 th of June 1849. we Traveled 24 miles to day and camped near the River. (Brady Island)

June 16th-This morning one of our Horses died leaving us only 3 to our wagon. The road to day is sandy. The ground in places incrusted with salaratus or soda; in the afternoon some of our company thought they Saw Buffalo ahead of us and left the wagons to get a shot at them, when they came near they found the supposed Buffalo to be the Horses belonging to the company who had gone ahead of us at the crossing of Wood river the same that had first organized with us and left us at Council Bluffs, we came up and camped near them by a small Lake. Traveled 22 miles to day.

June 17th-This morning after going a mile and a half we came to a very large spring of cold water at the head of Pawnee Swamp 293 miles from the Council Bluffs, went on to the last Timber on the north side of the river and camped about 3 Oclock 12 miles below the junction of the North and South Platte. Traveled 15 miles to day.

June $18 \mathrm{th}$-we remained at our encampment to Cook for our journey there being no more Timber except a lone tree on the north side of the river for a distance of 200 miles.

June 19th-This morning soon after starting we saw several large droves of Buffalo. Two companies went in persuit of them; The foremost company soon killed a large Bull, about the time we finished dressing it the other company came up having killed a Bull, a Cow and a young Heifer but we had so much meat already that we did not go back for them; While stoping to dress our Buffalo a man on foot came up with us (Isaac Shuck from Louisa County Iowa) he had Traveled the whole distance about 600 miles alone and on foot till he overtook us. We Traveled 15 Miles to day and camped on North Bluff creek.

June 20th-We passed over Sand Hills and camped on Petite creek.

June 21st-We camped about sundown in the Prairie, a Tremendous storm coming on just as we stoped for the night.

June $22 d-$ We camped late in the evening 2 miles above the lone tree and opposite Ash Hollow another storm coming on about sundown. Having been sick for the last 3 days I have no further recollection of events during that time. 
June $23 d$-Traveled 19 miles to day keeping close to the river, the road good considering the late rains. We are now 400 miles from the Couneil Bluffs not a stick of Timber in sight.

June 24th-To day at noon we passed some Bluffs on the right of the road, Some of the company ascended them and saw the Chimney Rock a distance of 45 miles. in the afternoon we passed the ancient Bluff ruins. They are high Bluffs composed of very soft stone and which from the washing of the rains or other causes have assumed the appearance of Ancient Castles or fortifications. We have Traveled 25 miles to day and camped in the Prairie.

June $25 t h$-Started before sunrise and went 5 miles to where the road comes to the river, and stoped there for Breakfast. we saw the Chimney Rock this Morning distance about 40 miles it looks like a pole set in the Prairie, after Breakfast we went 21 miles and camped a little below the Chimney rock which is situated on the opposite side of the River apparently about 3 miles from our encampment but from information upon which we can rely the distance is at least 10 miles this difference between actual and apparent distance is common in this part of the country and often brings disappointment to the emigrant, before he becomes accustomed to the delusion. The chimney Rock commences in the shape of a Cone then running up to a great height something in the form of a chimney from which circumstance it takes its name; Originally it was doubtless one of the largest isolated Rocks or Bluffs so common in the vicinity of the Platte river and being very soft the action of the frost and rain has reduced it to its present shape. We Traveled 24 miles to day.

June 26th-This day we Traveled 23 miles over a gravelly road and camped opposite Scotts Bluffs.

June 27th-To day in the forenoon we saw Laramie Peake being Then 45 miles from Fort Laramie. We Traveled 21 miles to day and camped on a creek $200 \mathrm{yds}$ south of the road. There has been much rain lately.

June $28 t h-$ Went 12 miles and stoped at noon at the first Timber on the north side of the river, for the last 200 miles further and camped near the River, Grass scarce for the first time since leaving the Council Bluffs, Wood plenty. Traveled 22 miles to day.

June 29th-Went 7 miles and arrived opposite Fort Laramie about 10 Oclock A. M. camped and remained till next morning, Grass very scarce; during the day Some Emigrants crossed from the Fort who had come up on the South Side of Platte River who informed us that the Cholera had been very fatal among the emigrants on that rout. 
June 30 th - Crossed the river and camped about 2 miles from Fort Laramie which is situated on the Laramie river, one and a half miles from its junction with North Platte, It was built by the American Fur Company and is surrounded by a wall eleven (11) feet high. The wall is made of Adobes which are bricks dried in the sun and put up without being burned. Being well situated for a Military Post, the Fort was purchased by the United States in 1848 it is now oceupied by 2 companies of Infantry and one company of Mounted Riflemen under the command of Major Sanderson. An office is kept here in which is registered the name and former residence of each emigrant traveling this rout. Laramie Peak (A Spur of the Rocky Mountains) is 55 miles from this place and may be seen at a distance of 100 miles. The Black hills commence here.

July 1 st-This day we spent in making arrangements to continue our journey, the next Settlement except Fort Bridger being at the Salt-Lake which is distant 509 miles. This place (Fort Laramie) is 522 miles from the Council Bluffs.

July 2d-This morning we bought a Horse for $\$ 100$ to replace the one that died on Platte river and started on our journey about noon and went 12 Miles through the Black hills when we came to a large spring but were disappointed to find it so warm as to be unfit for use but on going about a mile and a half down the creek we found good water and tolerable grass, where we camped.

July $3 d$-This day we reached Dead-Timber creek having Traveled 15 miles. wood \& water plenty, but grass Scarce. Still among the Black-hills.

Juty , th-Traveled 18 miles to day and camped on a small ereek with very little grass.

Juty 5th-Traveled only 13 miles to day and camped on La Bonte river a stream about 10 yards wide. 400 Crow Indians said to be camped a short distance up the river. Though we saw none of them. Peppermint grows wild here.

July 6th-Traveled 19 miles to day and crossed La Prele river where we saw some men diging a grave for a woman who had died leaving two small Infants (Twins) we went 4 miles further and camped on a small Creek at a cold spring, grass very scarce.

July 7 th-To day we remained at our encampment. Some of the company went out hunting and killed 3 Buffalo.

July $8 t h-$ Traveled 8 miles and came to Platte river which we had not seen for the last 80 miles (here we leave the Black hills) went 5 miles further and camped on Deer Creek at a celebrated 
camping place, grass and water scarce but from appearances it has once been abundant in this vicinity.

July 9 th-Went down Deer-Creek to its mouth and crossed the Platte river in a boat that had been found and repaired by the emigrants and camped on the North Side opposite the crossing 28 miles below the upper or Mormon Ferry. The water of Platte river much clearer and the Current more gentle than it is lower down.

Juty $10 t h$-Traveled 18 miles up the river and camped rather early having found some excellent grass, rather unusual for the last 12 days.

July $11 t h$-Continued our journey up the river and arrived opposite the upper Ferry about noon, went 15 miles further and stoped near sundown at some springs, but the water being represented as poisonous we did not use any of it and concluded to go on to the next water (13 miles) where we arrived about Midnight and camped on a small creek 3 miles below the Willow-Springs having traveled 38 miles to day.

July $12 t h$-Started very early and went on to the Willow-Springs where we stoped for breakfast, on reaching the Top of the hill after leaving the Willow-Springs we came in sight of the SweetWater Mountains. To day our road lay mostly through a level plain covered with loose sand, about sundown we came to the alkali ponds. Salaratus is found here in large quantities being produced by evaporation. We reached Sweet-Water river a little after dark. having traveled 21 miles to day over the worst road we have had since leaving home. This night we camped close to Independence Rock. The Sweet-Water river is about 20 yards wide at this place the water is very elear and entirely free from Alkali from which circumstance it probably takes its name, the Independence-Rock is situated on a level plain where the road first comes to Sweet-Water and is a solid Rock of Granite about 600 yards long 120 yards wide and 80 or 100 feet high. (Some say 120 feet high)

July $13 \mathrm{th}$-Early this morning being told that we could find grass about 4 miles north of the road we started in search of it and found a small Valey or Basin where several trains were encamped. We found plenty of grass and firewood but water rather scarce the wild sage grows to a most enormous size in this Valey. We stayed during the remainder of the day to recruit our Teams.

July 14th-This morning we started and passed a place called the Devils-Gate ( 2 miles from Independence-Rock) at this place the Sweet-Water is forced through a narrow passage between perpendicular Rocks several hundred feet high. Some of our company (with some difficulty) passed through the Gate which is about 
2 miles in length. (Traveled 18 miles and camped on SweetWater.)

July 15th-Traveled 19 miles to day and again camped on the Sweet-Water.

July $16 t h$-Traveled 24 miles to day and camped on the SweetWater 42 miles from the South-Pass.

July 17 th-To day at noon we left the Sweet-Water and traveled over a Mountain and camped on Strawberry-Creek. Came 20 miles to day.

July 18th-Traveled 10 miles and came to the river again 12 miles from the South-Pass, and camped; here we saw a large Bank of snow on the road-side near the river.

July 19th-Crossed the Sweet-Water for the last time, Traveled 12 miles and crossed the dividing ridge between the waters of the Atlantic and the Pacific about 1 Oclock P. M. The South-Pass is an elevated Plain about 7000 feet above the level of the Sea. The road passes about 20 miles South of the Wind-River Mountains which rise to the height of 13000 feet and are always covered with Snow. The Colorado the Yellow-Stone and Lewis's river head in these Mountains. After crossing the ridge we went 3 miles and Camped at the Pacific Springs. Traveled 15 miles to day.

July $20 t h-$ To day we crossed Dry-Sandy, Little-Sandy and camped after dark on Big-Sandy. They are all Tributaries of Green-River. We Traveled 30 miles to day.

July 21st-This morning we crossed the Big-Sandy Traveled 17 miles and camped at night on the same stream but did not cross it.

Juty $22 d$-Traveled 10 miles and came to Green River. Crossed over and camped 2 miles below the Ferry. Green-River is about 100 yards wide with a deep and rapid current. Traveled 12 miles to day.

July $28 d$-After traveling 5 miles down the river we found some good grass where we stoped till the morning of the 25th during our stay here we caught some Fish and killed some Sage-Hens.

July 25th-Left Green-River Traveled 16 miles and camped on Blacks-Fork another branch of Green-River.

July 26th-This morning we left the Old Mormon Road and took one bearing more to the north and camped at night on a small creek the water of which was very Muddy an unusual thing in this region. here we found plenty of grass We traveled about 20 miles to day.

Juty 27th-This morning soon after starting some of the company killed an Antelope. we traveled 15 miles and came to the old road at Fort-Bridger about 2 Oclock P. M. where we encamped. 
Fort-Bridger consists of a few Cabins surrounded by a Stockade of Pine logs. It was built in 1842 by $\mathrm{Mr}$. Bridger who still occupies it as an Indian Trading-Post. The soil appears to be rich in the immediate vicinity of the fort, but the climate is too cold to admit of farming or gardening. This place is on the head waters of Blacks-Fork in the immediate vicinity of the Utah Mountains which are covered with snow. We are now 114 miles from the SaltLake City.

Juty 28th-Left Fort-Bridger about noon Traveled 10 miles \& camped on a small creek.

Juty $29 t h-$ We started early and Traveled 4 miles to the Muddyfork where we saw the Grave of George Tallman a man with whom we were acquainted and who had passed us on the Sweet-Water, he died July 28th. This day about noon we crossed the ridge dividing the waters of the Pacific from the Great-Basin. We camped at night on Sulphur Creek a branch of the Bear River, having Traveled 21 miles to day.

July $30 t h$-After traveling 2 miles we crossed Bear-River the largest stream that empties into the Salt-Lake. Went 15 miles further and camped on a small creek near Cache Cave.

July 31st-Traveled 16 miles to day and camped on Echo-creek. A berry resembling the Black-Currant grows here in great quantities.

Aug. 1st-Traveled down Echo-Creek 5 miles when we came [to] the Red-fork of Weber River. here the road forked and a large Guide-Board is placed advising Travelers to take the new or left hand rout but we kept the old Mormon road which we afterwards understood was much the best. The Red-Fork is about 20 yards wide and has some timber growing on its Margin. we traveled down the river 4 miles where we crossed over went 4 miles further and camped on a small creek. Traveled 13 miles to day.

Aug. 2d-Traveled 17 miles and camped on Kanyon Creek. This evening we met the Mail going from Salt-Lake to independence Missouri.

Aug. $3 d$-Left Kanyon Creek and commenced ascending a high Mountain (covered with Timber mostly of the Balsam Fir) on reaching the Summit we came in sight of a portion of the Salt-Lake valey being then 17 miles from the City. in the afternoon we crossed another Mountain and at night camped on a small stream called the Last-Creek 9 miles from the City.

Aug. 4th-Proceeding down the creek about 5 miles we came to the Salt-Lake valey and reached the City about 11 Oclock A. M. We passed through without stoping crossed the Jordan or Utah out- 
let on a Toll-Bridge and camped about 3 miles from the Town where we remained till the Morning of the $10 \mathrm{th}$.

On the 24th of July 1847 a company of Mormons consisting of 120 men entered the valey of the Salt-Lake (Previously called Bear Valey) and took up Their residence on the site of the present City, In August and September about 600 wagons with families arrived. This was the first Settlement at Salt-Lake.

The City is 22 miles South-East of Salt-Lake on the Eastern side of the Valey, on a slightly inclined Plain. It is laid out into 19 Wards (the 20th Ward runing into a Spur of the Mountains is not included in the Corporation) each Ward is divided into Blocks of 10 Acres each and each Block in 8 Lots of an Acre and a quarter. The Blocks are divided by streets 8 rods wide and a stream of Spring-water from the mountain is conducted through each street throughout its entire length. The dwelling-houses are built of Adobes or unburned Brick. They are generally plain but neat and comfortable. They have a State-House built of Red Sand-Stone which they procure in the neighboring Mountains. They have also a Tithing-House in progress of building of the same material. Lime is found in this neighborhood in a natural state of decomposition and Plaster of Paris is found in the same vicinity. The outlet from the Utah Lake to the Salt-Lake runs a short distance west of the City, This stream which was formerly called the Utah outlet, the Mormons have appropriately enough named the Jordan and by this name it is now generally known. The Salt-Lake Valey is 60 or 70 miles in length and on an average about 20 miles wide a part of it is very fertile and produces enormous crops of Wheat, Barley, Oats and Garden vegetables. A considerable portion however of the Valey is entirely barren and unfit for cultivation. The whole Valey is said to contain a Population of about 20 thousand; five or six thousand of whom are in the eity. The Mormons have Settlements in several other Valeys within the Great-Basin.

The distances heretofore have been given as laid down in the Mormon Guide-Book which Terminates at this place. Hereafter they will be given according to the best information we can procure which may in some instances be slightly incorrect.

Aug. 10th-This morning about 10 Oclock we resumed our journey taking the Rout South of the Salt-Lake commonly called Hastings' Cut off. Traveled 15 miles and camped at the foot of a Mountain on the West side of the Valey.

Aug. 11th-This day in the forenoon we came to the Salt-Lake and went in bathing, the water is so heavy that a man will float upon it without making any exertions and so strongly impregnated with salt that no living animal is found to exist in it. When we came out we found ourselves covered with an incrustation of salt 
which proved annoying as we could procure no fresh water to wash it off. The Lake is said to be from 80 to 100 miles long North and South and 60 or 70 miles wide. There are several Islands in it upon some of which are high Mountains. We Traveled 25 miles to day and Camped at the Willow-Springs, where we remained during the 12th to recuit our Horses and Procure a supply of Hay for the Desert being the last opportunity we shall have.

Aug. 13th-Traveled 25 miles over a very dusty road and camped at a spring of Brackish water with very little grass or wood. here two men who were Traveling ahead of us passed us in the night returning towards Salt-Lake City with a Woman and little Girl whom they had found in the road having been abandoned and left by their Company. (They belonged to a company of Cherokees)

Aug. 14 th-We traveled 10 miles to day over a dusty road and about noon came to some springs of good water with plenty of grass but no fuel except wild sage. here we stoped for the remainder of the day.

Aug. 15th-This morning we took in a supply of water for the Desert and after Traveling 15 miles over a plain covered in places with salt we came to the foot of a Mountain where we found a spring of Brackish water plenty of fire-wood and some grass; here the Desert commences.

Aug. 16th-To day about 3 Oclock P. M. we commenced our journey across the Desert and at 7 Oclock on the Morning of the 18th we arrived at the first springs where we found plenty of water and grass where we remained till the Morning of the 21st. during the Trip we stoped in all about 8 hours. The distance across the Desert according to the best accounts is 91 miles. The first 8 miles is over a Mountain. The next twenty miles is a sandy plain, when we come to a ridge or low Mountain runing East and West, after crossing the ridge the road lies over a level plain covered more or less with salt. This plain is evidently covered with water during the winter season and probably communicates with the Salt-Lake which rises and falls several feet during the year. At the time we passed ponds of salt-water were still standing in many places.

Aug. 21st-This Morning we started and after going 5 miles we stoped at a large spring of rather Brackish water where we remained till 6 Oclock P. M. when we again started and at about 2 Oclock in the Morning we came to some holes of fresh water but found no grass here we stoped till 8 Oclock next Morning during this day and night we traveled about 25 miles. 
Aug. 22d-After Traveling 18 miles we came to a place called Slough-Springs at about 2 Oclock P. M. here finding good grass and water we encamped.

Aug. 23d-This day we did not start till Sundown and arrived about midnight at some warm Sulphur Springs having Traveled 18 miles here we found some grass, and stoped till next Morning. Some emigrants who are encamped here say it is only 6 miles to the Humboldt river, we think it is very doubtful.

Aug. $24 t h$-Started at 8 Oclock and crossed over a Mountain But instead of finding the Humboldt we came upon a dry sandy plain, during the day we could see what appeared to be groves of Timber and Lakes of water in different directions but they proved to be Optical delusions. The groves of Timber turned out to be sage brush and the Lakes to be plains of white sand. These deceptive appearances are not uncommon on these Deserts. in the Afternoon we came to the some Sulphur Springs similar to those we left in the Morning. Here we found a paper informing Emigrants that there was good grass and water about 2 Miles to the North of the road we accordingly went and found it as they had described and a large number of emigrants encamped. We have remained here till the morning of the 26th, 20 Miles to day.

Aug 26th-This Morning we started early and erossed over a Mountain into a valey and about noon came to grass and water where we stoped about 2 hours; after dinner we started again and crossed another Mountain about dark, seeing some fires ahead we kept on through the valey for about 5 miles where we found a company of emigrants here we encamped having Traveled about 30 miles to day. No word of the Humboldt yet.

Aug. 27th-This morning we found ourselves in a large valey extending appearantly about 20 miles to the North. On the South we could not see its terminations it is about 15 or 20 miles in width with a high Mountain runing along the west side. Grass and water in great abundance. This day our Horses having taken a stampede we only Traveled 14 miles our road was on the West side of the valey bearing nearly due South.

Aug. 28th-This Morning we started early and in the course of the day crossed a great many creeks formed by springs from the Mountains; grass still plenty and soil rich our road to day lay in the same direction as yesterday. We traveled 25 miles and Camped at one of the numerous springs.

Aug. 29th-Continued our journey in the same direction as yesterday and the day before, the country presenting the same appearance, having Traveled about 18 miles we encamped in a few miles 
of the lower end of the valey where it appears to be shut in by the Mountains. We found a large number of emigrants encamped and waiting for company. They had a map of the Country and had come to the conclusion that we had lost our road and had taken the rout taken by Fremont in 1845 , which goes by Walkers Lake. It is tolerably certain we are not on Hastings-Cutoff as the road does not appear to have been Traveled by Emigrants till the present season. The valey through which we have just passed is probably as large as the valey of the Salt-Lake. The soil seems to be equally as good and capable of supporting as large a Population. This valey is situated about 300 miles South West of Salt-Lake City, by the road.

Aug. 3oth-This morning our road bore westward across the Mountain we started in company with the other emigrants and after erossing the Mountain the road turned to the north precisely in an opposite direction from the course Traveled for the last three days. We Traveled 20 miles and camped on a small creek; not yet certain whether we are on the Fremonts rout or not.

Aug. 31st-This morning our Road continued north down the valey. The creek sometimes disappearing under ground then rising again, we Traveled about 18 miles to day and Camped at some wells of Brackish water which had been dug by former Emigrants.

Sept. 1st-This morning after Traveling about 7 miles down the valey we again come to water, the same creek reappearing. We Traveled down the valey till near sundown and camped on the creek having come 25 miles to day, during the forenoon Some emigrants found the bodies of two men supposed to have been killed by the indians, who are said to be very troublesome in this region though we have seen but one since crossing the Desert. We have been Traveling for the last 50 miles in an opposite direction from our rout down the Big Valey on the other side of the Mountain. We supposed this place to be not more than 20 miles from where we left on the Morning of the 27th Ultimo. We have come to the conclusion that we are not on Freemonts rout, but don't know where we are. Think we are not far from the Sink of the Humboldt.

Sept. 2d-After Traveling down the valey about 5 or 6 miles we came to a large creek coming in on our right hand from the South East; we kept down this creek in a North-west direction till noon where it enters a canyon and runs nearly due west. We started through the Kanyon at one Oclock P. M. and about sundown emerged into a valey of considerable size with a rich soil producing an abundance of Grass, Mustard and Flax. here we encamped having traveled 22 miles. The Kanyon through which we passed this evening is so narrow that in many places we had to Travel along the bed of the creek for a considerable distance there being no room 
on either side for a road. it is hemed in by precipitous mountains and overhanging Rocks. Across the valey 4 or 5 miles North of our encampment is the appearance of a larger stream coming in from the East, which we suppose to be the Humboldt though Some of the company think Otherwise; We Shall probably see in the morning.

Sept. $3 d$-This morning after going about 4 miles we found a paper Posted up on the road-side dated a few days back and apparently directed to some of the writers Friends informing them that they were then in a few miles of Walkers-River and about 200 miles from Sacramento City. After going about 2 miles further we came to a river of considerable size which we all supposed to be the Humboldt, notwithstanding the notice we had just seen on the road. Soon afterwards we were overtaken by some Emigrants who had come by the Northern Rout from the Salt-Lake. They informed us that the river down which we were now Traveling was Really the Humboldt and that we were now about 220 miles above the Sink. Though somewhat disappointed to find ourselves so far from the end of our journey we were glad at being now upon a road of which we had some knowledge. We had all been mistaken in regard to the Rout, the Road bearing much farther North than we had supposed for several days past. We Traveled 18 Miles to day and camped on a small creek near the River on the North side. Here upon comparing our notes of distances with those of a man who had Traveled the same Rout we found a variation of 12 miles in our calculations since leaving Salt-Lake a distance of about 450 miles From the best accounts given by other Emigrants the Road Traveled by us is about 120 miles further than the Northern rout from the Salt-Lake which comes in by the head of the Humboldt. We now think it probable that we left Hastings'-Cuttoff at the Slough-Springs on the 23d of August.

Sept. 4 th-This morning we left the valey of the Humboldt and Traveled over a range of Mountains 17 miles when we again came to the river. After going 3 miles further we camped having Traveled 20 miles.

Sept. 5th-To day in the forenoon we came to where the road forks one runing on each side of the river. We took the one on the North side, in the afternoon we came to the Grave of Ephraim Bowles of Keokuk County Iowa; from the inscription on the HeadBoard he was killed on the 19th of August in a Skirmish with the Indians about 10 miles North of the Road. We went 6 miles where we camped and killed a Beef which we had bought being nearly out of Provisions. Traveled 22 miles to day.

Sept. 6 th-Remained at our encampment for the purpose of drying our Beef. 
Sept. 7 th-Soon after starting we saw a number of Indians they showed Some hostile intentions but finally went off without molesting us We Traveled 25 miles to day and Camped near the River. Here we overtook a man and his wife Traveling with no other company except one man who was sick They camped with us.

Sept. $8 t h-$ This day we Traveled 22 miles besides losing about 12 miles by taking the wrong road (Probably Lawsons Cutoff) upon which we went about 6 miles and then came back to the road which we had left a short distance ahead of where we turned off. We camped near the river with about 25 men belonging to Woodwards Train from Cincinnati. One of their men very sick.

Sept. 9th-Woodwards Company started ahead of us. About 10 Oclock we passed them. The sick man having died they were diging his Grave. They overtook us in the afternoon. We Traveled till after dark and Camped together. We Traveled about 30 miles to day.

Sept. 10th-We traveled 20 miles to day and camped at a small Grove of Thorn-Bushes. The only Timber except small Willows that we had seen since reaching the Humboldt.

Sept. $11 \mathrm{th}$-Traveled 20 miles and camped in a head of the river among the Willows with but little grass.

Sept. 12th-This day Traveled till after dark before we camped making only 20 miles, We took our Horses across the river into a little bend but found very little grass.

Sept. 13th-This morning 2 Indian men and a Boy came to our camp with 2 Horses and 2 Mules, we talked of claiming them as stolen property but finally let them pass concluding that they were the rightful owners. We started and about 10 Oclock met the Owner inquiring for them. They had been stolen the night before. We reached the Big-Meadow after dark where we camped having Traveled 30 miles to day.

Sept. 14th-This morning my Brother David and Myself left the company with whom we had Traveled from home. Went on 5 miles and joined Dr. Bell's Train Our company being nearly out of Provisions we thought it best to separate.

Sept. 15th-To day we remained at our encampment and cut Hay preparatory to crossing the Desert between the Humboldt and Carson Rivers.

Sept. 16th-Resumed our journey Traveled 16 miles and camped close to Humboldt-Lake.

Sept. 17th-After Traveling 9 miles we crossed the Outlet from the Lake being merely a continuation of the river which finally 
sinks among the Sand-Hills a few miles below. About 1 Oclock P. M. started on the Desert which commences at the crossing of the Outlet and continues to the Carson River, the distance is said to be 40 miles. We Traveled all night and in the Morning at sunrise found ourselves about 6 miles from Carson River. Our Teams very tired and the worst part of the Desert before us. We held a consultation and concluded to take the Cattle from the Wagons and send them forward with a part of the company to the river while some of us should remain with the Wagons. This was accordingly done. Four of us remained in the Desert till about sundown when those who had gone ahead in the Morning returned with the Teams and we all went on to the River. Here we found quite a village of Tents a number of Traders having established themselves here temporarily for the purpose of trading with the Emigrants. They were selling Flour at 20 cents per pound which we considered cheap having paid one Dollar a pound at the Big-Meadows. The Destruction of property on the Desert during the present season has been immense. At the time we crossed it was estimated that 5 thousand head of Horses, Mules and Oxen were lying dead in a distance of 40 miles; incredible as this statement may seem it perhaps falls short of the actual number. The destruction of Wagons and other property was in proportion. Our company lost 2 Horses and an other company who Traveled with us lost 32 head of Oxen. It is supposed that the Cattle generally died from the effects of the Alkali water at the crossing of the outlet. The Carson river is about 30 yards wide much the same size as the Humboldt, it runs into a Lake and sinks, the water is clear and apparently free from Alkali.

Sept. 19th-This Morning we started again Traveling up the Carson river about 5 miles where we encamped and remained till next morning.

Sept. 20th-Started early but only went 3 miles till we stoped having a desert of 12 miles before us which we concluded not to cross till evening. Started again at 1 Oclock and Traveled 18 miles further stoping about 9 Oclock at night having Traveled 21 miles to day. We remained here till the afternoon of the $22 \mathrm{~d}$ to recruit our Teams. having found good grass, the first we have had since crossing the Desert.

Sept. 22d-Started at 1 Oclock P. M. Traveled 10 miles and camped. Turning our cattle onto an Island in the river we found good grass.

Sept. 23d-Started early, but Traveled only 10 miles to a Trading Post where we camped being told there was no more grass for the distance of 35 miles. 
Sept. 24th-This Morning we started expecting a Desert of 35 miles but after Traveling 16 miles were agreeably disappointed at finding good grass where we camped rather early in the afternoon.

Sept. 25th-After Traveling 4 miles we left the river and Traveled 12 miles over a Mountain coming to the river again at the lower end of a small valey. Traveled up the valey 3 miles and camped, having good grass and water. Same warm springs in this Valey. Traveled 19 miles to day.

Sept. 26th-Traveled 5 miles over a low ridge into what is called Carson Valey. Then 12 miles up the Valey and camped near the Mormon Station, having Traveled 17 miles to day. At this place there is a Log Cabin occupied by some Traders. A high Mountain is on our right covered with large Pine Timber. Some Gold-Diggers are said to be at work on the other side of the river.

Sept. 27th-Traveled 10 miles and camped near the head of Carson Valey where we remained till the afternoon of the 29th for the purpose of cuting hay for the Teams in crossing the Mountains. The best Springs I have ever seen are on Carson Valey.

Sept. 29th-Started in the afternoon. Traveled 4 miles and camped at the head of the Valey.

Sept. 3oth-After Traveling 5 miles we came to where the road turns to the right into a large Kanyon through which it passes for 7 miles. This part of the road is much the worst we have Traveled over since leaving home, we reached the head of the Kanyon a little before sundown and after going about a mile further camped in a small Valey having Traveled 13 Miles to day.

October 1 st-Traveled 7 miles up the same creek which runs through the Kanyon and camped a short distance to the right of the road.

October 2d-After Traveling 3 miles we came to a small Lake where the road comes to the Mountain. This Lake is by some called the Red-Lake though this name is more generally applied to another Lake on the other side of the Mountain. This Mountain is a ridge of the Sierra Nevada and very steep we crossed it without much difficulty and reached the Valey on the western side in the afternoon where we encamped close to the Red-Lake. We traveled about 9 miles to day.

October $3 d$-This day we crossed the main ridge of the Sierra Nevada. This Mountain is not so steep as the one we crossed yesterday, but higher being 5 miles by the road from the Base to the Summit. There was some snow near the Top but none in the road. We reached the Summit about noon. And having Traveled 6 miles down the Western Slope we camped at a Small Creek in Rock 
Valey. This creek we supposed to be one of the head branches of the Cosumnes or Macosma. We Traveled about 11 miles to day.

October 4 th-After Traveling 6 miles we came to a place called Tragedy-Springs from three men having been killed there by the Indians; from an inscription on a tree elose by they were killed on the night of the 27th of June 1848. Their names were Daniel Browett, Ezra H. Allen and Henderson Cox. They are all buried in one Grave under a pile of Stones. After Traveling 2 miles further we came to a Trading Post about noon where we camped having come 8 miles to day. A young man from Henry County, named Allen Melton died at this place during the night.

October $5 t h$-After Traveling 7 miles we came to the LeekSprings about noon. Then 11 miles further to Camp-Creek a branch of the Macosma. We Traveled 18 miles to day.

October 6 th-This morning after Traveling 6 miles we came to a Trading-Post where Dr. Bell Sold his Wagon and Team reserving the use of them to Weaver-Town. We Traveled 9 miles further and Camped at another Trading-Post having come 15 miles to day.

October 7 th-This morning we started early and about noon came to Some Trading-Posts at Pleasant Valey (12 miles) in the afternoon we traveled 10 miles further arrived at Weavertown about dark. Having come 22 miles to day. Here our journey ends for the present after having Traveled according to our calculations 2200 miles since leaving home the greater part of the way through an uninhabited Country. After having been on the road 141 days. Weavertown which is some times called Weberville is situated on Weaver or Weber Creek a branch of the American river 8 miles west of Placerville (Commonly called Hangtown) and 50 miles East of Sacramento City.

Weavertown and Ringold may properly be called the same vilage. Though the eastern part which is first entered on the emigrant road is called Ringold and the lower part Weavertown.

Colonization Meeting. A meeting of the State Colonization Society will be held this (Friday) evening, at the Supreme Court Room, in the Capitol, at 7 o'elock. Judge Hall, of Burlington, Governor Lowe, and others are expeeted to address the meeting. By order of the executive committee. Samuel Storrs Howe, Cor. Sec'y. Tri-Weekly State Journal (Des Moines), Feb. 26, 1858. 
Copyright of Annals of Iowa is the property of State of Iowa, by \& through the State Historical Society of Iowa and its content may not be copied or emailed to multiple sites or posted to a listserv without the copyright holder's express written permission. However, users may print, download, or email articles for individual use. 